\section{原 著}

論文受付

2008年 8 月28日

論文受理

2008年11月12日

Code No. 522

\section{角度計測誤差がpresampled MTFへ及ぼす影響の検証と 角度計測の最適手法の提案}

\author{
東出 了・市川勝弘 ${ }^{1)}$ ・國友博史・大橋一也・川野 誠 \\ 名古屋市立大学病院中央放射線部 \\ 1 ) 金沢大学大学院医学系研究科保健学專攻
}

\section{緒 言}

デイジタル撮影システムのmodulation transfer function (MTF)を測定する際, ディジタル特有のエリアシ ングエラーを含まないpresampled MTFを求める必要 がある，MTF測定において代表的なスリット，エッ ジ，および矩形波チャート(それぞれ，スリット法, エッジ法，および矩形波チャート法)を媒体に用いて presampled MTFを求めるには, Fujitaらの方法 ${ }^{1)}$ の うにこれらの媒体を 2〜3傾けて撮影し，十分に細か い実効サンプリング間隔を有する合成プロファイルを 得る方法が有効である。 この際に, 正確なpresampled MTFを算出するためには合成プロファイルを正確に 作成することが必要となり，そのためのパラメータの
なかで傾斜角度は実効サンプリング間隔を直接決め るため, 精度の求められる重要な因子となる。われわ れは以前にエッジ法において，一定間隔のbinを用い て合成プロファイルを作成する方法を提案し，その 際に計測角度の誤差は $0.05^{\circ}$ 以内にする必要があると 報告 ${ }^{2}$ した。しかし，これらの角度計測の重要性につ いては，過去の研究報告において十分に議論されて おらず，正確な角度を決定する手法は現在まで明確 には示されていない.

本研究ではスリット法, エッジ法, および矩形波 チャート法における傾斜角度の計測誤差が, presampled MTF值へ及ぼす影響の程度をシミュレーション によって明らかにした。また, 角度計測の手法とし

\title{
Influence of Angle-measurement Error on Pre-sampled MTF and Proposal of an Optimal Technique of Angle Measurement
}

\author{
Ryo Higashide, Katsuhiro Ichikawa,') Hiroshi Kunitomo, Kazuya Ohashi, and Makoto Kawano \\ Central Department of Radiology, Nagoya City University Hospital \\ 1 ) Division of Health Sciences, Graduate School of Medical Science, Kanazawa University \\ Received August 28, 2008; Revision accepted Nov. 12, 2008; Code No. 522
}

\section{Summary}

The presampled modulation transfer function (MTF) is recognized as the established metric for characterizing the resolution performance of a digital imaging system. In the past, the three general approaches for assessing the presampled MTF were using the angulated slit, angulated edge, and angulated square-wave test pattern all of which are tilted slightly against the column direction of the detector. In all methods, it is important to determine the exact angle of the respective test devices. In this study, we examined the influence of angle-measurement error in three test devices and the optimal technique of angle measurement. These results demonstrated that the influences of angle-measurement error in each method were equal. We also investigated three angle-measurement techniques using trace of objects, Hough transfer, and comparative observation of synthetic profiles. These results suggested that the technique using synthetic profiles was the most optimal technique in the angle measurement. Through use of the technique, angle-measurement error was completely overcome. This technique will contribute to improved accuracy of presampled MTF measurements.

Key words: modulation transfer function (MTF), digital imaging system, presampled MTF, angle 


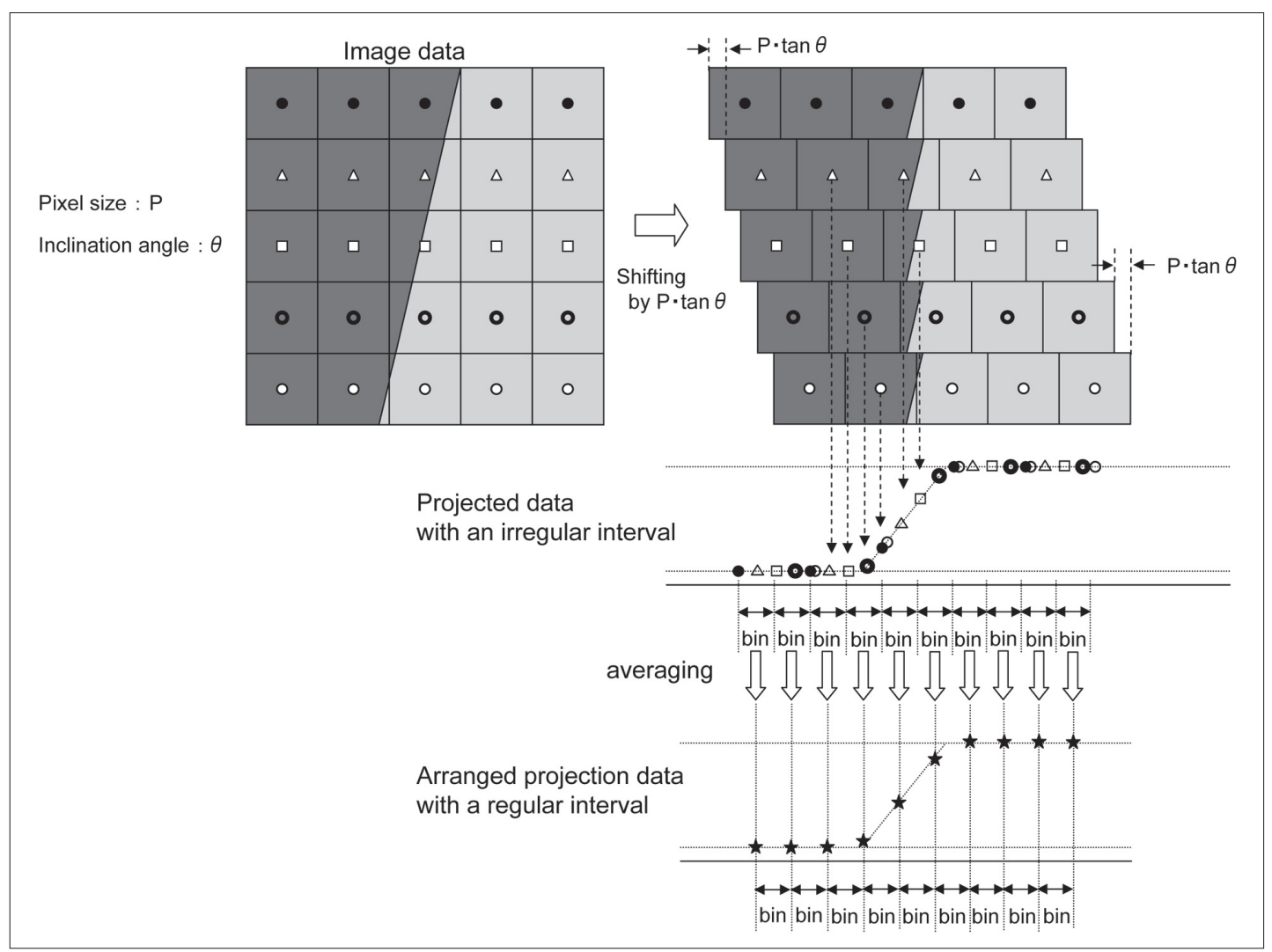

Fig. 1 Schematic diagram of a method for creating the synthetic edge profile with a regular data interval from the angled edge's image.

て，画像のトレースによって角度を求める方法, 画像 のハフ変換によって角度を求める方法, プロファイル を視覚的に観察して角度を求める方法において検証 を行い，正確な角度決定における最適手法について 検討した。

\section{1. 方 法}

\section{1-1 合成プロファイルの作成方法}

Buhrら ${ }^{3)}$ は，エッジの傾斜角度により合成に使うラ イン数の決定を行い, 理論的には不均等となる合成 後の各点の配置を，均等な間隔で調整して合成プロ ファイルを得る方法を用いた。この方法では，理論的 配置と調整後の配置の差が大きいほどMTFの結果に 及ぼす誤差は大きくなった。われわれはこの方法を 発展させ，以前の報告 ${ }^{2}$ において，Fig. 1のように，均 等間隔のbinによって複数のデー夕点を平均する手法 を提案し，良好な結果を得た。

この方法は，画像データのピクセル間隔Pとエッジ の傾斜角度 $\theta$ によって定まるシフト幅 $\mathrm{P} \times \tan \theta$ により， データ点をシフトさせながら投影する点ではBuhrらの 方法と似ている。 しかし，多くのデー夕点を用いて均 等間隔のbin内のデー夕平均をとるため, ばらつきを 軽減でき，特にエッジ法の微分操作においてデータ の振動を抑制できるため有効である，用いるbin幅の 設定はサンプリングピッチの10～20\%程度とすること で，その幅の平均によるMTFへの影響に対する補正 係数はナイキスト周波数で $1.004 〜 1.017$ とさい. bin 内のデー夕数は傾斜角度が 1 ４でわれわれが用いた $180 \times 180$ ピクセルの範囲にて合成を行えば約 14 点以上 (1/tan $\theta$ が整数もしくはほぼ整数となる $\theta$ は除く)とする ことができ，平均化による変動抑制効果が得られ る.このため, 今回はこの合成プロファイル作成法を エッジ法だけでなく，スリット法および矩形波チャー ト法にも用いることにした。

1-2 シミュレーション

\section{1-2-1 画像データの作成}

コンピュータシミュレーションによってガウス関数 による既知のMTF (真值)を持ち，任意の角度だけ傾 いたスリット，エッジ，矩形波チャートの画像を作成 した。データの作成においては，まず元画像のデー夕 をアナログ画像として近似し得るように，0.005 mmの 非常に細かい間隔で生成した。次に，このデータから 矩形のサンプリングアパーチャを模擬した矩形領域 の平均によってサンプリングして，ディジタル画像 データとした。作成画像のサンプリングピッチは 
$0.1 \mathrm{~mm}$ とし。 また, 矩形波チャート像はKyokko Type 1(化成オプトニクス社)のチャートを参考にし $\tau, \quad 0.5,1.0,1.5,2.0,2.5,3.0,4.0,5.0,6.0$, 8.0, 10.0cycles $/ \mathrm{mm}$ の周波数空を持つように作成し た。なお，画像データはMTFの測定において露光量 変換を必要としない線形なデータとした。

\section{1-2-2 スリット法におけるpresampled MTFの解} 析手順

スリット画像から傾斜角度 $\theta$ を求め, 前述した合成 プロファイルの作成方法によって均等な間隔の合成 プロファイルを得る。 この際にbin幅は, サンプリング ピッチの $10 \%$ となる $0.01 \mathrm{~mm}$ とした。われわれのエッ ジ法の検討2)では，この設定により，傾斜角度が 1 〜 4。であればナイキスト周波数におけるMTFの真值と 測定值の誤差率は $\pm 0.5 \%$ 範囲内に収まるという結 果を得ている。この均等な間隔に合成されたline spread function (LSF)に対してtruncation error ${ }^{4)}$ を防ぐ ために外挿処理 ${ }^{5,6)}$ を行い, フーリエ変換7)により presampled MTFを算出する.ここで，用いたbinによ る平滑化の補正を考慮する必要があり, bin幅に対応 した sinc関数の逆数による補正 ${ }^{8)}$ を行う。この際に用 いる補正係数C (f)は次式で表される.

$$
C(f)=\frac{1}{\operatorname{sinc}(\pi \cdot f \cdot d)}=\frac{\pi \cdot f \cdot d}{\sin (\pi \cdot f \cdot d)}
$$

$\mathrm{f}$ : 空間周波数 $[$ cycles $/ \mathrm{mm}]$

$\mathrm{d}$ : bin幅の間隔 $[\mathrm{mm}]$

1-2-3 エッジ法におけるpresampled MTFの解析 手順

エッジ画像から同様に均等な間隔の合成プロファ

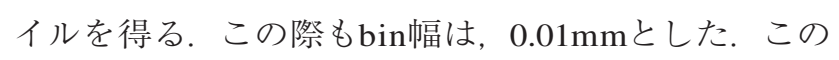
合成されたedge spread function (ESF)に対して隣接 差分による微分をすることでLSFを得る.LSFから presampled MTF算出まではスリット法と同様に行う. また, binによる平滑化の補正は(1)式と同様に行い, 更に隣接差分による微分に対する補正を(1)式のdを 差分間隔 $[\mathrm{mm}]$ とした式を用いて行った。

\section{1-2-4 矩形波チャート法における presampled MTF の解析手順}

矩形波チャート画像から同様に均等な間隔の合成 プロファイルを得る。この際もbin幅は, $0.01 \mathrm{~mm} と$ た.この合成した均等間隔のデータに対して市川らの 方法9)を使って presampled MTFを算出した。 市川らの フーリエ法の解析処理においては, 整数周期分の波 形デー夕を正確に抽出することが重要である。本研 究において抽出の始点と終点は以下のように半自動 的に求めた。 まず, 各周波数空の波形に対して最大 值と最小值を検索し, その中間レベルに引いた水平
ラインと波形との交点を検索する. 波形の各頂点の 両側における二つの交点の中間点を求めることで頂 点位置を推測し, その後, 波形データの左端からと 右端から 2 番目の頂点をそれぞれ始点と終点とし た. 検索結果はコンピュータ画面上に各周波数空の 波形とともに表示し, 各検出点を視覚的に観察して 適切かどうか判断して, 不適切な場合は表示された 波形上の点を補正した。また, binによる平滑化の補 正を(1)式により行った.

\section{1-3 傾斜角度の計測誤差の影響}

コンピュータシミュレーションによってガウス関数 による既知のMTF (真值)を持ち, 過去の報告から妥 当と思われる 2 および 3 傾けたスリット像, エッジ 像, 矩形波チャート像を作成した。 なお, 画像サイズ はスリット像およびエッジ像は $180 \times 180$ ピクセル, 矩 形波チャート像は $818 \times 180$ ピクセルとして, 合成に用 いるライン数は 180 とした。傾斜角度の計測誤差によ る影響を検証するため, 各画像の傾斜角度 $2^{\circ}$ に対し て合成に用いる角度を $2 \pm 0.30^{\circ}$ の範囲で $0.15^{\circ}$ 間隔とな る1.70, 1.85, 2.00, 2.15, 2.30とした際のpresampled MTFを求めた. また, 各画像の傾斜角度 $3^{\circ}$ に対して も同様に合成に用いる角度を2.70, 2.85, 3.00, $3.15,3.30^{\circ}$ とした際のpresampled MTFを求めた。

\section{1-4 角度計測の手法による測定精度の比較}

角度計測の手法として, 画像のトレースによって角 度を求める方法, 画像のハフ変換によって角度を求 める方法, およびプロファイルを視覚的に観察して角 度を求める方法の三つの手法において測定精度の比 較を行い, 角度決定に適した手法の検討を行った。 用いたハフ変換は, 画像から線分や円を抽出する手 法としてよく知られている。この検討ではスリットと エッジの画像を用いて検証を行った。矩形波チャー トでの検証を除いたのは, 矩形波チャート画像から 傾斜角度を求める際も矩形波チャートのエッジ部分 を使うことから，エッジに扮ける評価結果をそのまま 適用できるためである.

画像のトレースによる方法では, 汎用画像処理ソ フトであるImageJ ${ }^{10)}$ を用いた。 画像表示を行い, それ ぞれの測定対象となる像に対して移動や拡大などを 用いることで, Fig. 2の直線ABのように像の傾きに正 確なトレースを行った. トレース後に, このソフトの 計測機能を使って傾斜角度を求めた。

ハフ変換による方法では，スリット画像の直線部や エッジ画像にソーベルフィルタ処理を加えて検出した 境界線に対して 2 值化を行い, 八フ変換処理 ${ }^{11 \sim 13)} に$ よって直線部の検出とその傾斜角度の計測を行っ 


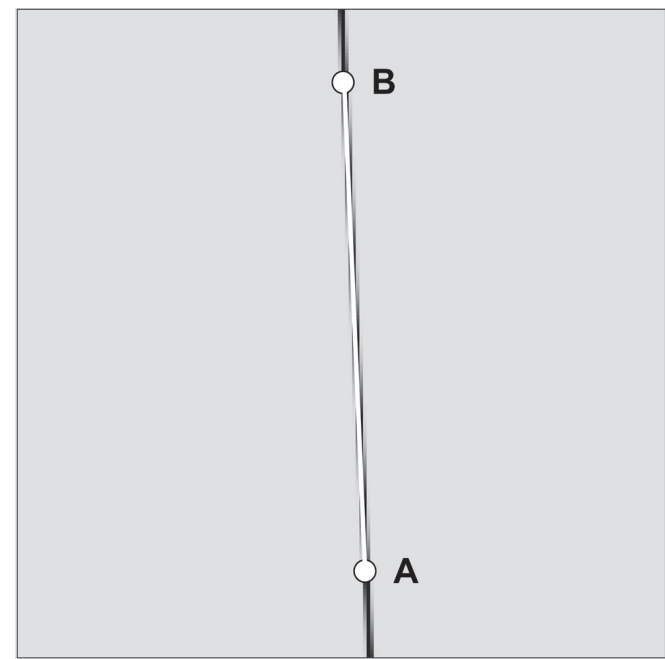

Fig. 2 Trace method.

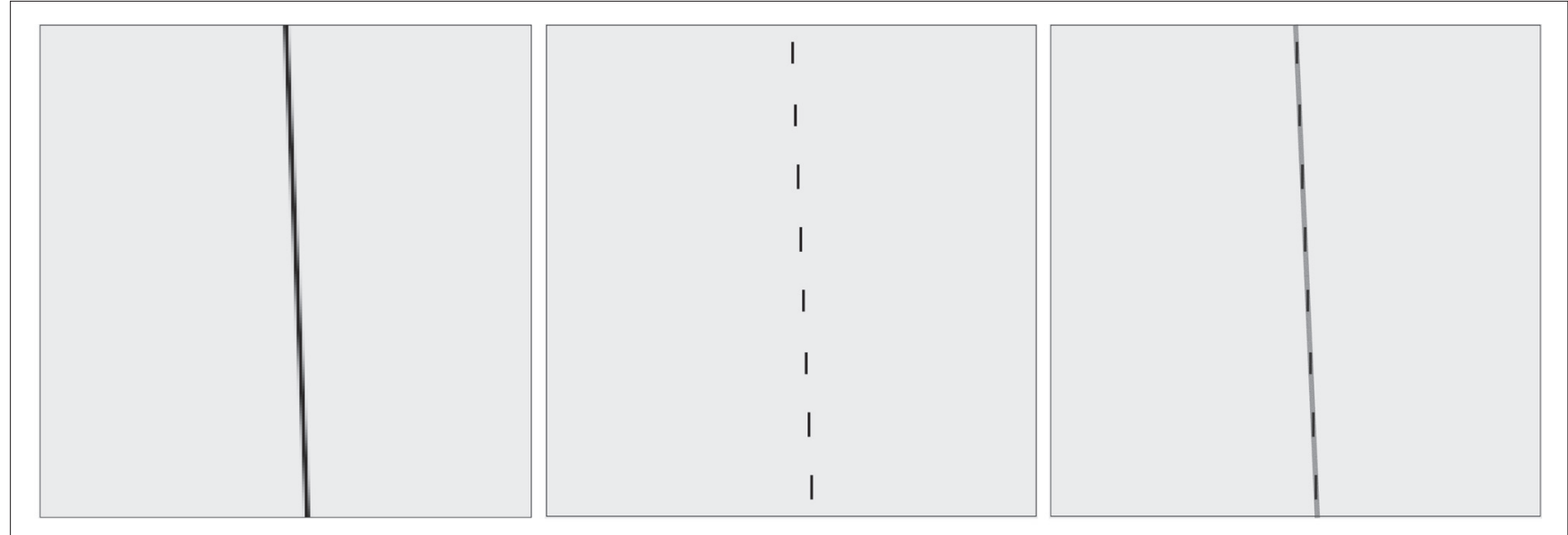

Fig. 3 Method using the Hough Transform

(a) slit image, (b) binary image, (c) analysis by Hough transform.

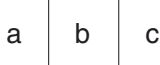

た.なお, 2 值化の閯值は線部の最大信号值の約 $90 \%$ から $0.2 \%$ 程度の間隔で最大信号值に向けて変化 させて，算出される傾斜角度が一定の值を示したと ころで傾斜角度值とした．Fig. 3にハフ変換による方 法にてスリット画像の傾斜角度を求める手順を示し た（a)のスリット画像に 2 值化を行い, (b)の画像と する. 2 值化した $(\mathrm{b})$ の画像に対して，八フ変換処理 をすることで(c) 画像のように直線検出を行う。ハフ 変換処理では, 直線検出を行う際に直線の傾斜角度 を求めることから角度值が計測される.

プロファイルの観察による方法は，われわれが以 前にエッジ法で提案した方法2)である. Fig. 1に示し た過程で，binにて平均される前の投影デー夕点の分 布をコンピュータ画面に表示する。単純な閾值処理 によって求めた角度をもとにわずかな角度間隔 $\left(0.01^{\circ}\right)$
にて角度值を増減して，その分布の変化を観察す る。角度誤差が大きい場合は，Fig. 4(a) (b)のように プロファイルが幅を持った分布として観察され, 誤差 が小さくなるにつれてFig. 4(c)のように収束して 1 本 の曲線のような分布となる。実験では，観察者がこの 収束度合いを判断して，正しいと思われる角度を決 定した。

各方法における測定精度の比較を行うために、コ ンピュータシミュレーションによって, 傾斜の角度が $1.43 ， 2.00 ， 2.52^{\circ}$ となるスリット画像 3 枚抢よびエッ ジ画像 3 枚を作成した。画像抢よびプロファイルか ら角度を求める方法に対しては 7 名の診療放射線技 師にて角度測定を行った。 また，八フ变換による方法 では，コンピュータプログラムによる自動計測值を他 の 2 法の結果と比較した. 

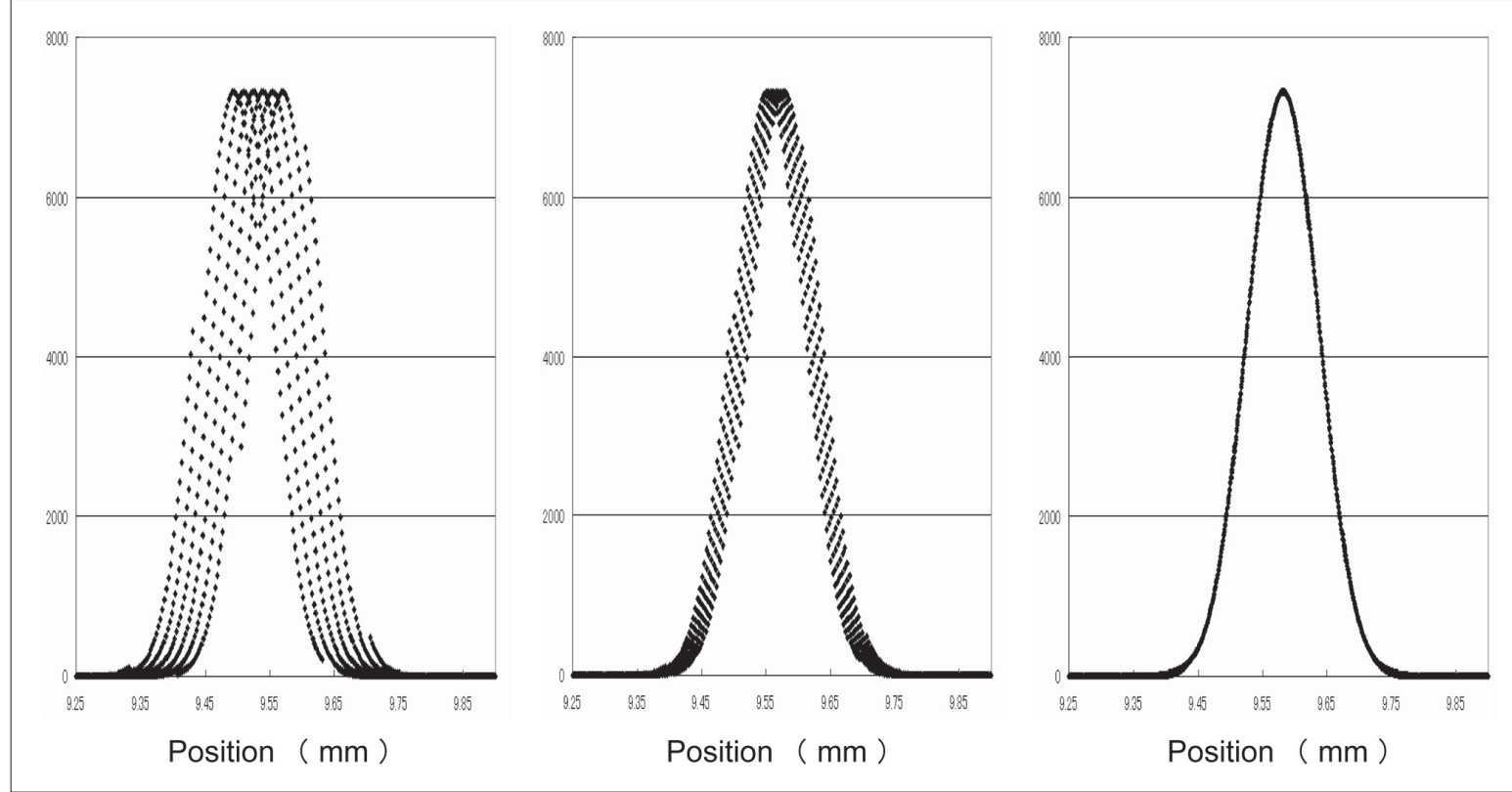

Fig. 4 Profile method.

Created synthetic profiles for two angle errors of (a) $0.3^{\circ},(\mathrm{b}) 0.1^{\circ}$, and (c) true angle.

$\mathrm{a}|\mathrm{b}| \mathrm{c}$
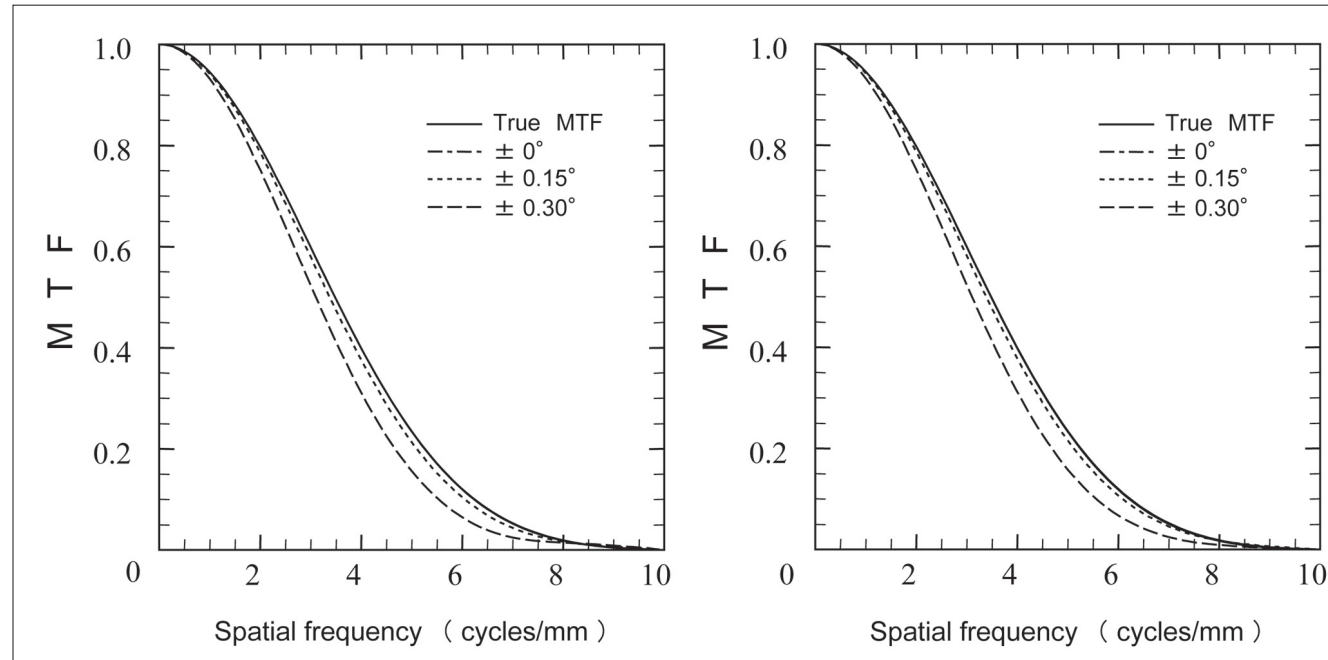

Fig. 5 True MTF and calculated MTFs for angle errors in cases of true angle: (a) $2^{\circ}$ and (b) $3^{\circ}$ on the slit method.

$a \mid b$

\section{2. 結 果}

\section{2-1 傾斜角度の計測誤差の影響}

傾斜角度が 2 および $3^{\circ} の$ 各画像に対して, プロ ファイルの合成に用いる各角度によるpresampled MTFをFig. 5〜7に示す. Fig. 5はスリット法, Fig. 6は エッジ法, Fig. 7では矩形波チャート法における presampled MTFの変化を示した。

$\pm 0^{\circ}$ はTrue MTFにほほ一致し, $\pm 0.15^{\circ}$ と $\pm 0.30^{\circ}$ に おいては+とーの結果はほぼ同様の誤差であった。ま た，Fig. 8はスリット法，エッジ法，矩形波チャート 法の傾斜角度が $2^{\circ}$ 画像に対してプロファイルの合
成に用いる角度を $2^{\circ}, 2 \pm 0.15^{\circ}, 2 \pm 0.30^{\circ}$ とした際の presampled MTF值とMTFの真值との差分を示した。

スリット法, エッジ法, 矩形波チャート法の角度計 測誤差によるpresampled MTFへの影響はほほ等し く, 画像の傾斜角度と合成に用いる計測角度の誤差 が大きいほどpresampled MTFの值は低下した。 ナイ キスト周波数手前の4.0cycles/mmでMTF值の誤差は 最大となった。 また, 2 および $3^{\circ}$ の異なる傾斜角度で あっても, 角度の計測值と角度の真值との誤差が同 等であればMTFの結果に与える影響もほぼ同等で あった 

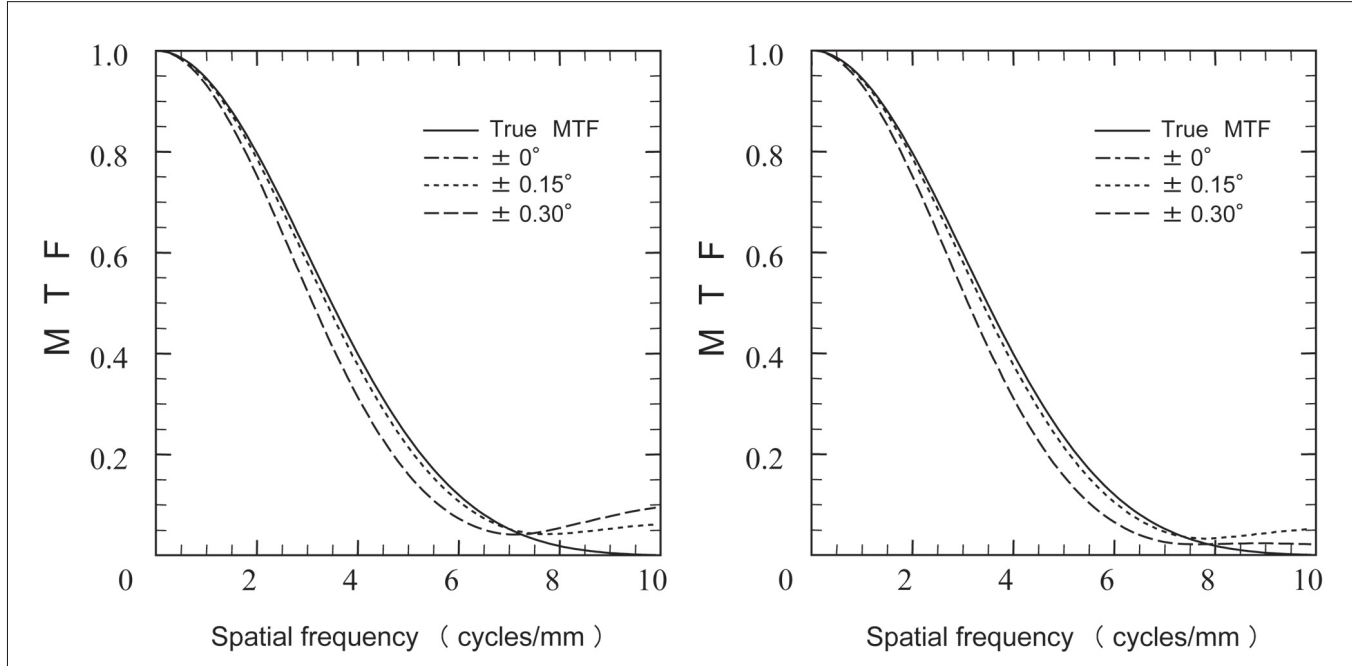

Fig. 6 True MTF and calculated MTFs for angle errors in cases of true angle: (a) $2^{\circ}$ and (b) $3^{\circ}$ on the edge method.
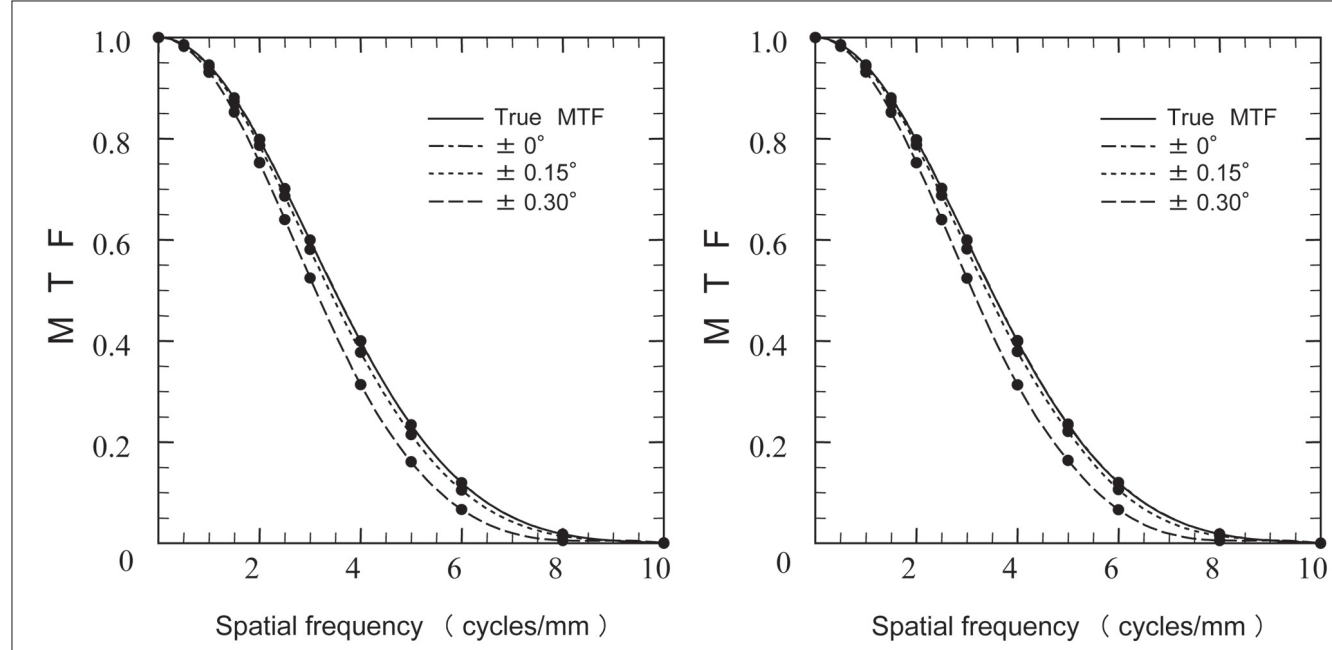

Fig. 7 True MTF and calculated MTFs for angle errors in cases of true angle: (a) $2^{\circ}$ and (b) $3^{\circ}$ on the square-wave method.

Dark round markers denote measured data for respective square-wave frequencies.
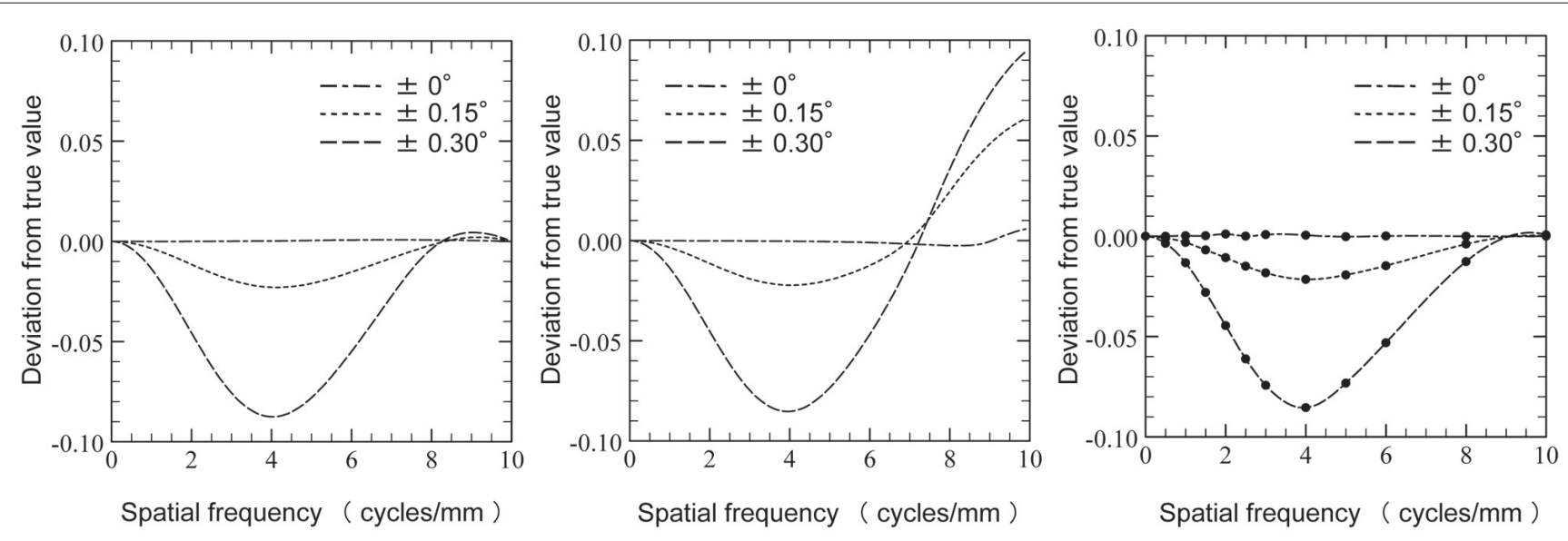

Fig. 8 Deviation from the true MTF value of measured MTF as function of spatial frequency for (a) the slit method, (b) the edge method, and (c) the square-wave method. 


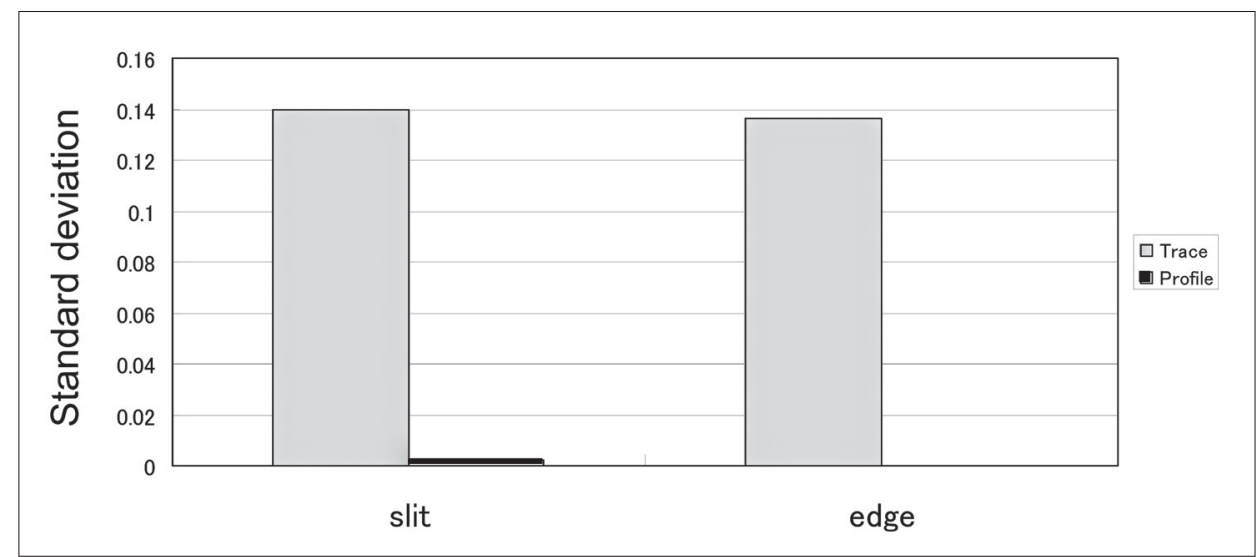

Fig. 9 Comparison of standard deviations of measured angle by seven observers for two measurement methods (trace method and profile method). The observers measured the angles for three true angles that were set to the simulated slit and edge images.

\section{2-2 角度計測の手法による測定精度の比較}

Fig. 9は画像のトレースによる方法とプロファイル の観察による方法について, 観察者 7 名における測 定値のばらつきを標準偏差によって評価したもので ある.

画像のトレースによる方法では観察者間による測 定結果のばらつきが大きくなった，また，測定結果の 平均は真值が $1.43,2.00,2.52^{\circ}$ の場合にスリットにお いて1.31，1.98，2.45 となり，エッジにおいては1.40, 2.01，2.56 となった。 プロファイルの観察による方法 では，観察者間のばらつきはほとんどなく，2.00傾斜 のスリット画像に㧈いて観察者 1 名が $+0.01^{\circ}$ の誤差を 示した以外は, 真值に等しい值を計測した。一方, 八フ変換による方法では, 真值の $1.43,2.00,2.52^{\circ} に$ 対して測定結果はスリットでは1.42，1.98，2.48， エッジでは $1.41,1.98,2.48^{\circ}$ となり, $0.01 \sim 0.04^{\circ}$ の測 定誤差を示した。

\section{3. 考 察}

傾斜角度の計測誤差についてはスリット法, エッ ジ法, 矩形波チャート法において同様の傾向を示 し, 角度誤差が大きいほどpresampled MTFの值は低 下した。 1-3 の計測誤差の影響については合成に用い るライン数を180として検証を行ったが, 実際のMTF 測定ではスリット法抢よびエッジ法と比べて矩形波 チャート法ではチャートの形状を考えると合成に用い るライン数は少なくなる. Fig. 10は, 矩形波チャート 法において合成に用いるライン数を100とした場合の 角度誤差の影響を調べた結果である。

このように本論文で採用した多数デー夕を使った 合成方法では, 合成のライン数が少なくなると presam- pled MTFに対する角度誤差の及ぼす影響は減少す る。この結果は矩形波チャート法に扔ける少ない合 成ライン数が，有効に作用するとも考えられる。 しか し，本合成法に招いて合成ライン数の減少は $1 \mathrm{bin}$ 内 に収まるデー夕数を減少させることになり, 合成後の プロファイルの誤差が生じやすくなる，このため，本 合成法に扮いて合成ライン数を減らして角度誤差の 及ぼす影響を小さくすることよりも，正確な角度測定 に努めることの方が重要であることは明らかである. なぜなら, 正確な角度決定は, 多くの合成ライン数の 使用を可能とし, binによる平均化をより有効なもの とするためである。

角度計測の手法とその精度については, 画像のト レースによる方法では測定の精度は画像上のライン やエッジ境界部をトレースする際の境界判別の個人 差に依存することになる。このため, 測定結果は観 察者間の差が大きく，最も測定精度が低くなった。 八 フ変換によって角度を求める方法ではわずかに真值 との誤差を生じるが, 比較的精度の高い測定が可能 であった、プログラムの更なる改良・最適化によりプ ロファイルを視覚的に観察して角度を求める方法と同 等程度の測定精度を確保することは可能と考えられ る. しかし, この方法は 2 值化に扔ける䦨值の決定 基準が曖昧であることや採用するプログラムのアル ゴリズムに依存して測定精度が変化するといった点 で汎用性に欠けるという問題点を持ち合わせてい る。 それらに対して，プロファイルの観察による方法 は容易なプログラムで実行可能であり，目視による角 度調整を行うことで正確な角度計測ができる．Fig. 4 (a) (b)のように角度誤差を生じた場合, この方法で は，0.1の角度誤差を含んだFig. 4(b)の場合に扔いて 


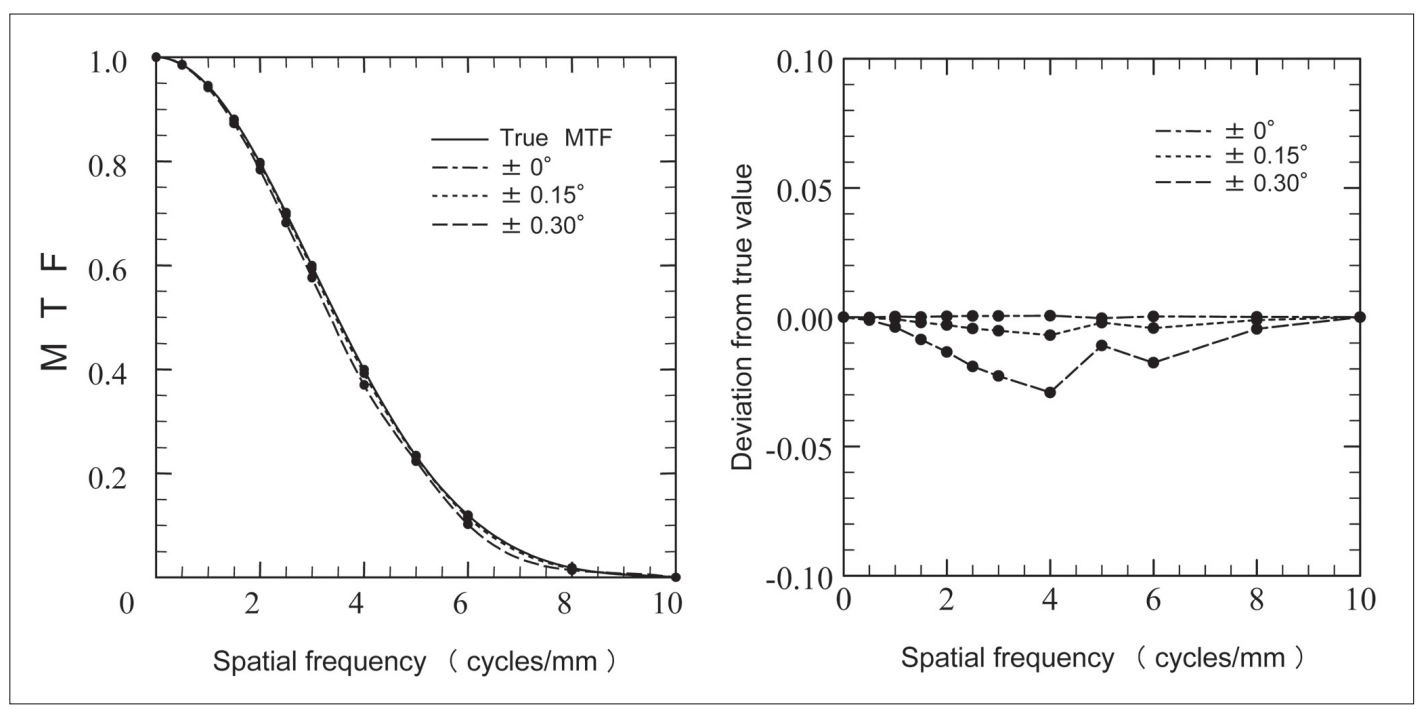

Fig. 10 (a) True MTF and calculated MTFs for angle errors, and (b) Deviation from the true MTF value of measured MTF as function of spatial frequency, when the line number used for synthesizing the profile of the square waves was 100.

$a \mid b$

も明らかに角度の誤りを認識することができる。よっ て合成されたプロファイルの収束の度合い(合成点の 集合が細い曲線となる度合い)を視覚的に確認しなが ら角度の決定をするこの方法は，観察者間のばらつ きが生じにくく，正確な角度計測を可能とする。ま た，計測に要する時間もスリット画像 3 枚とエッジ画 像 3 枚の計 6 画像に対して, プロファイルの観察に よる方法では 7 名の平均で 1 分 51 秒となり, 1 画像に 対して19秒程度の時間にて計測を行える，画像の卜 レースによる方法に打いては 7 名の平均で 8 分 50 秒 となり,これらは 1 画像に対して 1 分 28 秒程度となっ た。これらの結果より, プロファイルの観察による方 法は測定の精度が高く, かつ短時間で計測が可能で あることが示された，以上のことから，傾斜角度計測 の手法としてプロファイルの観察による方法が最適で あると考える。な掞この方法を更に有効にするために は，プロファイルの変化を自動的に認識する手法の開 発が有効であると考えており，その開発を今後の課 題としたい.

\section{4. 結 語}

スリット法, エッジ法, 矩形波チャート法のpresampled MTF測定において, 傾斜角度の計測誤差が大き くなる程，測定結果の值は低下する傾向を示した。ま た， 3 法における角度誤差の影響はほぼ同じであり， 合成に用いるライン数が多い程, 影響が大きくなっ た。ライン数は合成プロファイルの合成精度に影響 するために，これを多くするためにも傾斜角度を正確 に計測することが重要である。角度計測の手法とし てプロファイルを視覚的に観察して角度を求める方法 が精度に優れる方法であり，この手法を用いることで presampled MTFの測定精度に関わる重要な因子であ る傾斜角度の計測誤差についての問題を解決するこ とが可能となった。

\section{謝 辞}

本研究に御協力いただきました当院中央放射線部 諸氏に感謝いたします。 


\section{参考文献}

1) Fujita H, Doi K, Giger ML, et al. Investigation of basic imaging properties in digital radiography. 6. MTFs of II-TV digital imaging systems. Med Phys 1985; 12(6) : 713-720.

2) 東出了, 市川勝弘, 國友博史, 他. エッジ法による presampled MTFの簡便な解析方法の提案と検証. 日放技 学誌 $2008 ； 64(4) ： 417-425$.

3) Buhr E, Günther-Kohfahl S, Neitzel U. Accuracy of a simple method for deriving the presampled modulation transfer function of a digital radiographic system from an edge image. Med Phys 2003; 30(9) : 2323-2331.

4) 内田 勝, 金森仁志, 稲津 博 著, 日本放射線技術学会 編. 3-2 レスポンス関数. 放射線画像情報工学 I. 通商産 業研究社, 東京, 1980：181-187。

5) 桂川茂彦. 4 画像の評価. 医用画像情報学. 南山堂, 東 京, $2002: 66-91$.

6) 畑川政勝, 青木雄二, 朝原正喜, 他. 委員会報告. 増感 紙一フィルム系のMTF測定におけるスリット法と矩形波 チャート法の比較。日放技学誌 1996 ；52(5)：701-708.
7) 小川智哉 監修, 渋谷道雄, 渡邊八一 著. Excelで学ぶ フーリエ変換。東京：オーム社, 2003.

8) Cunningham IA, Fenster A. A method for modulation transfer function determination from edge profiles with correction for finite-element differentiation. Med Phys 1987; 14(4): 533-537.

9）市川勝弘, 國友博史, 櫻井貴裕, 他. 矩形波チャート像 のフーリエ変換によるプリサンプリングMTFの新しい測定 法. 日放技学誌 2002；58(9)：1261-1267.

10) Abramoff MD, Magelhaes PJ, Ram SJ. Image Processing with ImageJ. Biophotonics International 2004; 11(7): 36-42.

11) 田村秀行. 6 画像特徵の抽出. コンピュータ画像処理. オーム社, 東京, 2002：181-206。

12) 谷口慶治. 72 值画像の処理. 画像処理工学-基礎編. 共立出版, 東京, 1996：107-131.

13）酒井幸市. 52 值化画像. デジタル画像処理入門. CQ 出版社, 東京, 2002：63-100.

Fig. 1 傾けたエッジ画像から規則的なデータ間隔となる合成エッジプロファイルを作成する方法の概要図

Fig. 2 画像のトレースによる方法

Fig. 3 ハフ変換による方法

(a)スリット画像, （b)2 值化画像，（c）ハフ変換解析

Fig. 4 プロファイルによる方法

(a) $0.3^{\circ}$ および $(\mathrm{b}) 0.1^{\circ}$ の角度誤差によって作成された合成プロファイルと (c) 正確な角度によって作成された合成プロファイ ル

Fig. 5 スリット法において真の角度が $(\mathrm{a}) 2^{\circ}$, (b) $3^{\circ}$ の場合に誤差を含んだ角度によって計算されたMTFと真のMTF

Fig. 6 エッジ法に扔いて真の角度が $(a) 2^{\circ}$ ，（b) $3^{\circ}$ の場合に誤差を含んだ角度によって計算されたMTFと真のMTF

Fig. 7 矩形波チャート法において真の角度が (a) $2^{\circ}$, (b) $3^{\circ} の$ 場合に誤差を含んだ角度によって計算されたMTFと真のMTF マーカー(黒丸)は各周波数の矩形波から測定された值を示す.

Fig. 8 測定されたMTF值に対するMTF真值からの偏差の空間周波数による変化

(a)スリット法, (b)エッジ法, (c) 矩形波チャート法

Fig. 9 観察者 7 名による二つの測定方法(トレース法拈よびプロファイル法)から求めた角度值の標準偏差の比較 観察者は真の角度值が既知である三つのスリットとエッジのシミュレーション画像の角度を測定した.

Fig. 10 矩形波チャートのプロファイル合成のために使用するラインを100とした場合

(a)真のMTFと誤差を含んた角度から計算されたMTF

(b)測定されたMTF值に対するMTF真值からの偏差の空間周波数による変化 